\title{
ANALISA PENGARUH LIKUIDITAS, PROFITABILITAS DAN LEVERAGE TERHADAP NILAI PERUSAHAAN DAN IMPLIKASINYA TERHADAP KEBIJAKAN DEVIDEN PADA CONSUMER SERVICE INDUSTRY, HOTELS, RESTAURANT AND LIESURE SECTOR DI BURSA EFEK SINGAPURA
}

\author{
Riski Dwi Nugroho \\ Fakultas Ekonomi, Magister Manajemen, Universitas Pamulang \\ dosen02296@unpam.ac.id
}

\begin{abstract}
Abstrak
Tujuan dari penelitian ini adalah bagaimana pengaruh Likuiditas, Profitabilitas, dan Leverage terhadap Nilai Perusahaan dan implikasinya terhadap Kebijakan Deviden pada Consumer Service Industry, Hotels, Restaurant and Liesure Sector di Bursa Efek Singapura (SGX). Data penelitian ini terdiri dari neraca, laporan laba/rugi dan laporan nilai deviden selama 4 (empat) tahun, terhitung mulai dari periode tahun 2013 sampai dengan tahun 2016. Variabel bebas dari penelitian ini adalah Likuiditas, Profitabilitas dan Leverage, sedangkan variabel terikatnya adalah Nilai Perusahaan dan variabel moderatenya adalah Kebijakan Deviden.

Metode yang diaplikasikan dalam penelitian ini yaitu penelitian dengan analisa data kauntitatif dan secara deskriptif. Metode akumulasi data dilakukan dengan menggunakan populasi dan sample.

Hasil perhitungan menyatakan bahwa Likuiditas memiliki pengaruh terhadap Nilai Perusahaan, dimana secara parsial uji hipotesis CR terhadap PER memiliki pengaruh positif dan signifikan yaitu (2.200547>2.02809) dan nilai probabilitas CR lebih rendah dari konstanta $(0.0339<0.05)$. Profitabilitas memiliki pengaruh terhadap Nilai Perusahaan. Dimana secara parsial, uji hipotesis NPM terhadap PER yang dijadikan alat ukur memiliki pengaruh negative yang signifikan dengan t-hitung lebih kecil dari t-tabel $(-10.04784<2,02809)$ dan nilai probabilitas NPM lebih kecil dari konstanta $(0,0000<$ 0.05). Leverage tidak memiliki pengaruh terhadap Nilai Perusahaan. Dimana secara parsial, uji hipotesis DAR terhadap PER yang dijadikan sebagai alat ukur tidak memiliki pengaruh dan tidak signifikan dengan t-hitung lebih kecil dari t-tabel $(-1.879704<$ $2,02809)$ dan nilai probabilitas DAR lebih besar dari konstanta $(0.0678>0.05)$. Likuiditas, Profitabilitas dan Leverage memiliki pengaruh terhadap Nilai Perusahaan. Dimana secara simultan, uji hipotesis CR, NPM dan DAR terhadap PER yang dijadikan sebagai alat ukur memiliki pengaruh dan signifikan dengan $\mathrm{F}$ tabel $<\mathrm{F}$ hitung $(38.36989$ $>2,87$ ) dan probabilitas (prob) sebesar 0.000000 terlihat lebih rendah dari nilai signifikan 0,05 , dengan persentase keterkaitan antara variable dependen terhadap variabel independen sebesar $74.20 \%$, dan $25.80 \%$ dipengaruhi faktor lain. Nilai Perusahaan memiliki pengaruh terhadap Kebijakan Deviden. Dimana secara parsial, uji hipotesis PER terhadap DPR yang dijadikan sebagai alat ukur memiliki pengaruh dan signifikan dengan F hitung $>\mathrm{F}$ tabel $(6.374424>4,10)$ dimana angka probabilitas (prob) yaitu 0,0001 lebih rendah nilanya dari 0,05 .
\end{abstract}




\author{
Kata Kunci :Likuiditas, Current Ratio, Profitabilitas, Net Profit Margin, Leverage, \\ Debt To Asset Ratio, Nilai Perusahaan, Rasio Harga Terhadap Pendapatan, \\ Kebijakan Deviden, Dividend Payout Ratio.
}

\begin{abstract}
"This study aims to find out how the influence of Liquidity, profitability, and leverage to the value of the company and its implications to dividend policy on consumer service industry, hotels, restaurants and liesure sector in Singapore Stock Exchange (SGX). This research data consist of balance sheet, profit/loss report and dividend value report for 40 (forty) years, starting from period of 2013 until 2016. Independent variable of this research is liquidity, profitability and leverage, while the dependent variable is the value of the firm and its moderate variable is dividend policy.

The method applied in this research is research with quantitative and descriptive data analysis. Data accumulation method is done by using population and sample.

The calculation results state that Liquidity has an influence on Company Value, wherein partially the CR hypothesis test on PER has a positive and significant influence (2.200547> 2.02809) and the CR probability value is lower than the constant (0.0339 $<0.05)$. Profitability has an influence on Company Value. Where partially, the NPM hypothesis test against PER which is used as a measuring instrument has a significant negative effect with $t$-count smaller than $t$-table $(-10.04784<2.02809)$ and the probability value of NPM is smaller than a constant $(0.0000<0.05)$. Leverage has no effect on Company Value. Where partially, the DAR hypothesis test against PER which is used as a measuring instrument has no effect and is not significant with t-count smaller than $t$ table $(-1.879704<2.02809)$ and DAR probability value is greater than a constant (0.0678> 0.05 ). Liquidity, Profitability and Leverage have an influence on Company Value. Simultaneously, the hypothesis test of CR, NPM and DAR on PER which is used as a measuring instrument has an influence and is significant with $F$ arithmetic $>F$ table (38.36989> 2.87) and the probability (prob) of 0.000000 looks lower than the significant value of 0,05, with the percentage of the relationship between the dependent variable on the independent variable amounting to $74.20 \%$, and $25.80 \%$ influenced by other factors. Company value has an influence on dividend policy. Where partially, the PER hypothesis test against the DPR which is used as a measurement tool has an influence and is significant with $F$ arithmetic $>F$ table $(6.374424>4.10)$ set the probability value (prob) of 0.0001 is smaller than 0.05
\end{abstract}

Keywords: Liquidity, Current Ratio, Profitability, Net Profit Margin, Leverage, Debt To Asset Ratio, Corporate Value, Price Earning Ratio, Dividend Policy, Dividend Payout Ratio. 


\section{PENDAHULUAN}

\section{A. Latar Belakang Masalah}

Berdirinya sebuah perusahaan harus memiliki tujuan yang jelas. Sebuah perusahaan pasti memiliki tujuan yang terkait dengan nilai perusahaannya, yaitu memaksimumkan laba dengan sebesar-besarnya dan meminimumkan modal perusahaan sekecil-kecilnya. Tujuan lain dari perusahaan yaitu memakmurkan pemilik perusahaan atau pemegang saham.

Dalam konteks memakmurkan pemilik perusahaan, likuiditas merupakan salah satu poin penentu perusahaan mendapat persetujuan investasi dan bisnis yang menguntungkan. Maka dari itu digunakanlah Current Ratio (CR) dalam pengukuran tingkat likuidasi. Suatu cara yang digunakan kurang dari satu tahun dalam rangka pengukuran kemampuan pemenuhan kewajiban jangka pendek didalam perusahaan. Tingkat aktiva lancar yang yang tinggi menandakan bahwa perusahaan mampu dalam pemenuhan kewajiban jangka pendeknya yaitu Current Ratio (CR) (Sartono, 2001:116).

Kemudian, pada penelitian kali ini rasio profitabilitas yang akan digunakan yaitu Net Profit Margin (NPM).
Menurut Alexandri (2008:200) rasio yang digunakan untuk melihat mampunya perusahaan untuk menciptakan laba setelah dipotong pajak dinamakan Net Profit Margin. Perusahaan dikatakan produktif jika nilai NPM semakin besar. Dan dengan kata lain dapat memberikan kepercayaan kepada investor untuk bersedia menanamkan modalnya atau berinvestasi. Harahap (2015:306) berpendapat bahwa Leverage Ratio yaitu kemampuan perusahaan yang dilihat berdasarkan ekuitas yang menggambarkan tentang upaya perusahaan dibiayai oleh hutang atau pihal eksternal perusahaan. Adapun rasio leverage yang digunakan dalam penelitian ini adalah Debt To Asset Ratio (DAR). Menurut Kasmir (2015:156) Debt to Asset Ratio adalah seberapa besar aktiva perusahaan berpengaruh terhadap pengelolaan aktiva dimana dapat dikatakan pula sebagai bagian dari penentuan antara total utang dengan total aktiva dengan menggunakan perhitungan rasio.

Berdasarkan pada data prariset yang dilakukan penulis bahwa nilai Current Ratio (CR) tertinggi yaitu $9.23 \%$ yaitu pada perusahaan Genting Singapore PLC, sementara itu nilai Current Ratio 
(CR) terendah yaitu $0.56 \%$ terdapat pada perusahaan Mandarin Oriental INTL Ltd. Kemudian nilai Net Profit Margin (NPM) tertinggi yaitu $96.67 \%$ terdapat pada perusahaan Centurion Coorporation Limited yang menandakan perusahaan tersebut memiliki laba bersih yang besar dan berdampak positif pada nilai saham dan jumlah dividen yang akan dibagikan. Sementara nilai terendah yaitu $1.22 \%$ terdapat pada perusahaan Soup Restaurant Group Limited. Kemudian untuk nilai dari Rasio hutang terhadap asset yaitu $95.27 \%$ dimiliki oleh perusahaan Hotel Grand Central Limited, sementara nilai terendahnya yaitu $13.09 \%$ terdapat pada perusahaan ABR Holding Limited. Berdasarkan tabel diatas dapat terlihat bahwa nilai variabel DAR terlihat lebih tinggi dibandingkan variabel lain, hal ini terjadi karena nilai hutang terhadap asset pada perusahaan yang dijadikan sampel penelitian cukup besar.

Kemudian jika berdasarkan data prariset yang dilakukan penulis dapat dilihat bahwa terdapat fluktuasi terhadap nilai pendapatan dari beberapa perusahaan. untuk perusahaan yang mengalami peningkatan pendapatan setiap tahunnya secara konsisten yaitu pada perusahaan Hotel Royal Limited. Kemudian, untuk perusahaan yang mengalami penurunan pendapatan hanya di tahun 2015 yaitu ABR Holding Limited, Centurion Coorporation Limited, Hotel Grand Central Limited, Mandarin Oriental INTL Ltd. Kemudian, untuk perusahaan yang mengalami penurunan 2 kali dalam 4 tahun terakhir yaitu pada tahun 2014 dan 2016 yaitu perusahaan Amara Holding Limited. Kemudian, perusahaan yang mengalami penurunan di 2 tahun terakhir yaitu perusahaan Genting Singapore PLC. Kemudian, untuk perusahaan yang mengalami penurunan secara konstan terjadi pada Hotel Properties Limited. Dan perusahaan yang mengalami penurunan di tahun terkahir yaitu 2016 terjadi pada perusahaan Soup Restaurant Group Limited dan Stamford Land Coorporation Limited.

Kemudian, pada penelitian kali ini yang menjadi alat ukur terhadap nilai perusahaan yaitu menggunakan Price Earning Ratio (PER). Menurut Brigham dan Houston (2010:150) Rasio harga/laba (Price Earning Ratio) merupakan sikap investor yang akan rela membayar setiap dolar laba yang dilaporkan atas hasil dari price per 
share ratio terhadap earning per share.

Penilaian pemodal dimasa mendatang dapat dilakukan dengan mencari rasio dari harga terhadap laba (Simamora, 2000:531).

Berdasarkan data prariset nilai Price Earning Ratio (PER) bahwa nilai tertinggi didapat oleh Genting Singapore PLC dengan rasio $72.58 \%$ ditahun 2014. Sedangkan nilai terendah didapat oleh Mandarin Oriental INTL Ltd dengan rasio 0.52\% ditahun 2013. Terlampir pada lampiran yang digunakan dalam penelitian ini bahwa jumlah saham yang beredar tidak sebanding dengan harga yang yang dtetapkan, sebagai suatu acuan bahwa jumlah saham yang beredar pada perusahaan yang memiliki nilai PER tertinggi yaitu Genting Singapore PLC adalah sebesar 12.106.580.000 saham yang beredar, dengan harga yang didapat sebesar $\$$ 5.573.050.000. sedangkan untuk perusahaan yang mendapat nilai PER terendah yaitu Mandarin Oriental INTL Ltd adalah sebesar 1.003.000.000 saham yang beredar, dengan harga yang didapat sebesar \$ 50.200.000. Oleh karenanya minimnya nilai laba yang dihasilkan oleh perusahaan bisa diakibatkan oleh hal tersebut.
Menurut Riyanto

(2011:265)

Kebijakan Deviden adalah satu sikap didalam perusahaan tentang hak pemegang saham terkait dengan penentuan nilai pendapatan yang akan dibagikan dalam bentuk deviden atau digunakan sebagai operasional perusahaan. maka dari itu, salah satu alat yang dijadikan ukuran bahwa kebijakan dividen yang dilakukan perusahaan baik atau buruk adalah Rasio Pembayaran Dividen.

Berdasarkan perhitungan hasil prariset diatas menunjukkan bahwa data bersifat fluktuatif dan variatif, dimana banyak terjadi kenaikan dan penurunan nilai baik dari variabel indpenden, dependen dan moderate. Berdasarkan uraian singkat tentang latar belakang penelitian in, maka judul dalam penelitian ini yaitu :

"ANALISAPENGARUH
LIKUIDITAS,PROFITABILITAS
DAN LEVERAGE TERHADAP
NILAI PERUSAHAAN DAN
IMPLIKASINYA TERHADAP
KEBIJAKAN DEVIDEN PADA
CONSUMER SERVICE
INDUSTRIAL,HOTELS,RESTAUR
ANT AND LIESURE SECTOR DI
BURSA EFEK SINGAPURA"

\section{B. Rumusan Masalah}

Telah diketahui bahwa banyak hal yang sudah dipaparkan penulis terkait judul didalam latar belakang penulisan ini, maka penulis menentukan beberapa masalah yang terkait dengan judul yaitu: 
1. Bagaimana pengaruh likuiditas secara parsial terhadap nilai perusahaan pada Consumer Services Industrial, Hotel, Restaurant and Liesure Sector di Bursa Efek Singapura?

2. Bagaimana pengaruh profitabilitas secara parsial terhadap nilai perusahaan pada Consumer Services Industrial, Hotel, Restaurant and Liesure Sector Sector di Bursa Efek Singapura?

3. Bagaimana pengaruh leverage secara parsial terhadap nilai perusahaan pada Consumer Services Industrial, Hotel, Restaurant and Liesure Sector di Bursa Efek Singapura?

4. Bagaimana pengaruh likuiditas, profitabilitas dan leverage secara simultan terhadap nilai perusahaan pada Consumer Services Industrial, Hotel, Restaurant and Liesure Sector di Bursa Efek Singapura?

5. Bagaimana pengaruh nilai perusahaan terhadap kebijakan deviden pada Consumer Services Industrial, Hotel, Restaurant and Liesure Sector di Bursa Efek Singapura?

\section{Tujuan Penelitian}

Dengan adanya beberapa problematika yang telah dirumuskan, maka tujuan dari penelitian ini yaitu :

1. Untuk memahami dan mencari kebenaran pengaruh likuiditas terhadap nilai perusahaan pada Consumer Services Industrial, Hotel, Restaurant and Liesure Sector di Bursa Efek Singapura secara parsial.

2. Untuk mengetahui bagaimana pengaruh profitabilitas terhadap nilai perusahaan pada Consumer Services Industrial, Hotel, Restaurant and Liesure Sector Sector di Bursa Efek Singapura secara parsial.

3. Untuk mengetahui bagaimana pengaruh leverage terhadap nilai perusahaan pada Consumer Services Industrial, Hotel, Restaurant and Liesure Sector di Bursa Efek Singapura secara parsial.

4. Untuk mengetahui bagaimana pengaruh likuiditas, profitabilitas dan leverage terhadap nilai perusahaan pada Consumer Services Industrial, Hotel, Restaurant and Liesure Sector di Bursa Efek Singapura secara simultan.

5. Untuk mengetahui bagaimana pengaruh nilai perusahaan terhadap kebijakan deviden pada Consumer 
Services Industrial, Hotel,

Restaurant and Liesure Sector in Singapore Exchange.

\section{Manfaat Penelitian}

Diharapkan pada penelitian kali ini menjadi dasar atau dijadikan bahan pertimbangan kala perusahaan melakukan evaluasi terkait dengan nilai perusahaan dan kebijakan deviden yang akan ditetapkan.

II. TINJAUAN PUSTAKA, KERANGKA BERFIKIT DAN HIPOTESIS

\section{A. Tinjauan Pustaka}

\section{Analisis Rasio Keuangan}

Analisis rasio keuangan merupakan sebuah analisa dalam bentuk rasio yang dihitung dan diperoleh dengan cara membandingkan jumlah antara jumlah satu dengan yang lainnya. (Irham Fahmi, 2013:106)

\section{Rasio Likuiditas}

Kasmir (2012:110) berpendapat bahwa Liquidity Ratio adalah kebutuhan jangka pendek yang diupayakan perusahaan agar terpenuhi kurang dari satu tahun. Rasio yang digunakan dalam penlitian ini adalah Current Ratio, rumusnya yang digunakan seperti dibawah ini:

$$
\text { Current Ratio }=\frac{\text { Aktiva Lancar }}{\text { Hutang Lancar }} \times 100 \%
$$

\section{Rasio Profitabilitas}

Kasmir (2012:114) berpendapat bahwa Proftiability Ratio merupakan suatu periode yang dibutuhkan perusahaan dengan segala upayanya untuk menciptakan laba atau keuntungan, dan dengan cara dihitung dalam bentuk rasio. Dalam penelitian ini rasio yang digunakan yaitu Net Profit Margin. Dan rumusnya adalah sebagai berikut:

\begin{tabular}{|l|} 
Net Profit Margin $=\frac{\text { Net Income }}{\text { Sales }}$ \\
\end{tabular}

\section{Rasio Leverage}

Seperti diketahui, dalam mendanai usahanya, perusahaan memiliki beberapa sumber dana. Sumber-sumber dana yang dapat diperoleh adalah pinjaman atau modal sendiri.

Keputusan untuk memilih menggunakan modal sendiri atau modal pinjaman haruslah digunakan beberapa perhitungan yang matang. Dalam hal ini menurut Munawir (2011:83) leverage ratio (rasio solvabilitas) merupakan kewajiban 
jangka panjang ataupun likuidasi perusahaan sebagai tanggung jawab perusahaan dalam upaya yang akan dipenuhi dalam periode tertentu dan dihitung dalam bentuk rasio.

Maka rumus yang digunakan yaitu Rasio Hutang terhadap Aset, dimana rumusnya yaitu:

Debt To Asset Ratio $=\frac{\text { Total Debt }}{\text { Total Aset }} \times 100 \%$

5. Nilai Perusahaan

Menurut Untung dan Hartini (2006:2) nilai perusahaan merupakan nilai yang hampir sering dikaitkan dengan harga saham dan cara pandang sebuah perusahaan dimata investor Secara umum banyak metode dan teknik yang dikembangkan dalam penilaian perusahaan, salah satunya adalah menggunakan pendekatan Price Earning Ratio (PER), dan rumus yang digunakan adalah:

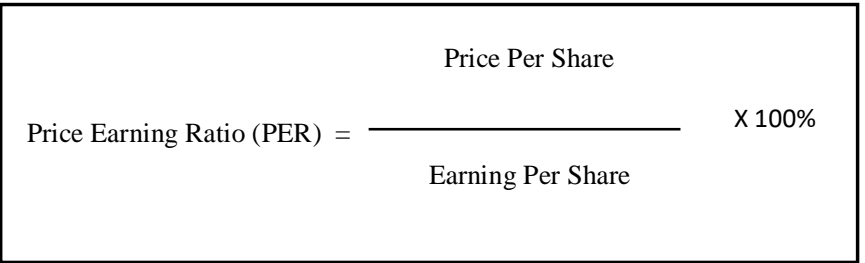

\section{Kebijakan Dividen}

Sunariyah (2004:48) berkata bahwa dividen adalah sebuah hasil yang didapatkan perusahaan yaitu laba yang merupakan bagian dari hak pemegang saham untuk dibagikan sesuai dengan porsinya yang bersumber dari laba perushaan penerbit saham. maka rumusnya adalah:

\section{B. Hipotesis Penelitian}

Hipotesis yang telah dirumuskan terkait dengan ada tidaknya keterkaitan antara variabel indpenden $(\mathrm{X})$ terhadap variable dependen (Y) serta implikasinya variabel dependen (terikat) terhadap variabel moderate (Z), maka penulis merumuskannya sebagai berikut:

\footnotetext{
1. $\mathrm{H}_{0}$ : Tidak terdapat pengaruh yang signifikan antara likuiditas perusahaan terhadap Nilai Perusahaan

$\mathrm{H}_{1}$ : Terdapat pengaruh yang signifikan antara likuiditas

$\mathrm{H}_{0}$ : Tidak terdapat pengaruh yang signifikan antara profitabilitas perusahaan terhadap Nilai Perusahaan

$\mathrm{H}_{2}$ : Terdapat pengaruh yang signifikan antara profitabilitas perusahaan terhadap Nilai Perusahaan

3. $\mathrm{H}_{0}$ : Tidak terdapat pengaruh yang signifikan antara leverage perusahaan terhadap Nilai Perusahaan
}

\section{METODOLOGI PENELITIAN}

\section{A. Tempat, Waktu dan Sifat} Penelitian

Informasi didapatkan dengan melakukan penelitian pada beberapa perusahaan yaitu Consumer Service Industry, Hotels, Restaurant and Liesure Sector yang berada di Singapura. Dimana data keuangannya didapat dari bursa Efek Singapura yang beralamat di 2 Shenton Way, \#02-02 SGX Centre 
1, Singapore 068807 atau melalui situs remisnya di http://www.sgx.com . kemudian Penelitian ini dimulai dari bulan Juni 2017 sampai dengan september 2017. Penelitian ini juga dilakukan dengan beberapa tahapan, Tahapannya secara berurut adalah tahap proposal penelitian, olah data dan penyelesaian laporan. Penelitian ini bersifat deskriptif dengan pendekatan kuantitatif, karena dalam penelitian ini memberikan penjelasan dan gambaran tentang kondisi laporan keuangan perusahaan yang ada di Bursa Efek Singapura.

\section{B. Populasi dan Sampel}

Menurut Sugiyono (2007:51) populasi merupakan sebuah tahap didalam penelitian untuk menggeneralisasi suatu wilayah dan terdiri atas subyek dan obyek yang memiliki karakteristik dan kualitas tertentu untuk dilakukan penetapan kesimpulan. Didalam penelitian ini penulis menetapkan bahwa obyek penelitian dilihat dari sudut pandang populasi yaitu Consumer Service Indsutry dan tercatat di Singapore Stock Exchange sebanyak 21 perusahaan.
Menurut Sugiyono (2011:62) sampel adalah bagian dari populasi yang mewakili karakteristik obyek atau subyek yang sedang diteliti. Sampel dalam penelitian ini adalah perusahaan yang bergerak di Hotels, Restaurant and Liesure Sector di Singapore Stock Exxchange, dimana terdapat kelengkapan data hanya 10 perusahaan. Teknik penarikan sampel dalam penelitian ini menggunakan teknik purposive sampling.

\section{Rancangan Analisis dan Uji Hipotesis}

\section{Rancangan Analisis}

Sebuah rancangan analisis yang menggunakan teknik analisis regresi linier berganda dengan dilakukan uji melalui aplikasi eviews versi 9. Dan dibawah ini merupakan rincian dari setiap uji yang akan dilakukan yaitu:

\section{a. Uji Statistik Deskriptif}

Menurut Sugiyono (2017:147), statistik deskriptif adalah sebuah cara dalam menggambarkan data yang sudah dikumpulkan tanpa dilakukan penarikan kesimpulan secara umum atau menyamakan unsur dengan langkah atau metode perhitungan statistic. Descriptive Statistics dapat menjabarkan data dalam mode table, grafik, diagram lingkaran, pictogram, 
perhitungan modus, median, mean (pengukuran tendensi sentral), perhitungan desil, persentil, perhitungan penyebaran data melalui perhitungan rata-rata dan standar deviasi, perhitungan presentasi (Sugiyono, 2014:200).

\section{b. Estimasi Model Regresi Linier}

Model perkiraan atau persamaan matematis pada penelitian ini dengan Aplikasi Eviews versi 9 adalah :

$$
\begin{aligned}
& Y_{1, \text { it }}=\beta_{0}+\beta_{1} X_{1, \text { it }}+\beta_{2} X_{2, \text { it }}+\beta_{3} X_{3, \text { it }} \\
& + \text { cit } \\
& \mathrm{Z}_{3, \mathrm{it}}=\beta_{0}+\beta_{2} \mathrm{Y}_{2, \mathrm{it}}+\varepsilon \mathrm{it} \\
& \mathrm{Y}_{1, \mathrm{it}} \quad=\text { Nilai Perusahaan } \\
& \mathrm{Z}_{3, \mathrm{it}} \quad=\text { Dividend Payout Ratio } \\
& \mathrm{i}=\text { Perusahaan } \\
& \mathrm{t}=\text { Waktu/Tahun } \\
& \beta_{0} \quad=\text { Intersep } \\
& \beta_{1} \beta_{2} \beta_{3}=\text { Slope untuk setiap } \\
& \text { variabel Likuditas, } \\
& \text { Profitabilitas dan Leverage. } \\
& \mathrm{X}_{1, \mathrm{it}} \quad=\text { Likuiditas } \\
& \mathrm{X}_{2, \mathrm{it}} \quad=\text { Profitabilitas } \\
& \mathrm{X}_{3, \mathrm{it}}=\text { Leverage } \\
& \text { cit }=\text { Residual }
\end{aligned}
$$

Metode Regresi linier data panel terdiri dari 3 model, yaitu :

b.1 uji model common effect

b.2 uji model fixed effect

b.3 uji model random effect kemudian dalam pemilihan model yang tepat digunakan :

b.4 uji chow

b.5 uji haussman

\section{c. Uji Asumsi Klasik}

Menurut teorema Gaus Markov, pada regresi linier klasik berbasis model kuadrat terkecil atau Ordinary Least Square (OLS), diperlukan uji asumsi klasik (Sriyana, 2014:37). Uji ini akan terdiri dari uji normalitas, uji multikolinearitas, uji heteroskedastisitas, dan uji auto korelasi. Dimana uji ini dilakukan untuk mengetahui hasil regresi memenuhi kriteria BLUE.

\section{Uji Hipotesis}

Uji hipotesis merupakan uji untuk mengetahui kebenaran hipotesis yang ada dalam penelitian ini. Hipotesis yang akan digunakan dalam penelitian ini berkaitan dengan ada tidaknya hubunga antara variabel bebas dan variabel terikat, serta hubungan antara variabel terikat dengan variabel yang memoderatenya. Hipotesis nol $\left(\mathrm{H}_{0}\right)$ tidak terdapat pengaruh yang signifikan dan hipotesis alternative $\left(\mathrm{H}_{1}\right)$ menunjukkan adanya pengaruh yang signifikan dari variabel bebas terhadap variabel terkait. Uji hipotesis yang aka dilakukan adalah uji t, uji F dan uji koefisien determinasi. 


\section{HASIL DAN PEMBAHASAN}

1. Uji Hipotesis Variabel CR, NPM, dan DAR terhadap PER

a. Pengaruh Variabel CR, NPM dan DAR terhadap PER Secara Parsial (Uji t)

1) Pegaruh Current Ratio terhadap

Price Earning Ratio

Tabel 4.13

Analisis Regresi Data Panel Secara

Parsial

Pengaruh CR terhadap PER

\begin{tabular}{|c|c|c|c|c|}
\hline \multicolumn{5}{|c|}{$\begin{array}{l}\text { Dependent Variable: LOGPER } \\
\text { Method: Panel EGLS (Cross-section random effects) } \\
\text { Date: 09/06/17 Time: } 06: 34 \\
\text { Sample: } 20132016 \\
\text { Periods included: } 4 \\
\text { Cross-sections included: } 10 \\
\text { Total panel (balanced) observations: } 40 \\
\text { Swamy and Arora estimator of component variances }\end{array}$} \\
\hline Variable & Coefficient & Std. Error & t-Statistic & Prob. \\
\hline $\begin{array}{c}\mathrm{C} \\
\mathrm{CR}\end{array}$ & $\begin{array}{l}1.273718 \\
0.178066\end{array}$ & $\begin{array}{l}0.375490 \\
0.080919\end{array}$ & $\begin{array}{l}3.392152 \\
2.200547\end{array}$ & $\begin{array}{l}0.0016 \\
0.0339\end{array}$ \\
\hline \multicolumn{5}{|c|}{ Effects Specification } \\
\hline $\begin{array}{l}\text { Cross-section random } \\
\text { Idiosyncratic random }\end{array}$ & & & $\begin{array}{l}0.938632 \\
0.574181\end{array}$ & $\begin{array}{l}0.7277 \\
0.2723\end{array}$ \\
\hline \multicolumn{5}{|c|}{ Weighted Statistics } \\
\hline $\begin{array}{l}\text { R-squared } \\
\text { Adjusted R-squared } \\
\text { S.E. of regression } \\
\text { F-statistic } \\
\text { Prob(F-statistic) }\end{array}$ & $\begin{array}{l}0.115549 \\
0.092274 \\
0.567076 \\
4.964509 \\
0.031868\end{array}$ & \multicolumn{2}{|l|}{$\begin{array}{l}\text { Mean dependent var } \\
\text { S.D. dependent var } \\
\text { Sum squared resid } \\
\text { Durbin-Watson stat }\end{array}$} & $\begin{array}{l}0.508542 \\
0.595201 \\
12.21985 \\
1.541545\end{array}$ \\
\hline \multicolumn{5}{|c|}{ Unweighted Statistics } \\
\hline $\begin{array}{l}\text { R-squared } \\
\text { Sum squared resid }\end{array}$ & $\begin{array}{l}0.162403 \\
40.58224\end{array}$ & $\begin{array}{l}\text { Mean dependent va } \\
\text { Durbin-Watson stat }\end{array}$ & & $\begin{array}{l}1.738693 \\
0.464180\end{array}$ \\
\hline
\end{tabular}

2) Pengaruh Net Profit Margin terhadap Price Earning Ratio

"Tabel 4.14

Analisis Regresi Data Panel

Secara Parsial

Pengaruh NPM terhadap PER
Dependent Variable: LOGPER

Method: Panel EGLS (Cross-section random effects)

Date: 09/10/17 Time-11:36

Sample: 20132016

Cross-sections included: 10

Total panel (balanced) observations: 40

Swamx and Arora estimator of component variances

\begin{tabular}{|c|c|c|c|c|}
\hline Variable & Coefficient & Std. Error & t-Statistic & Prob. \\
\hline \multirow{4}{*}{$\underset{\text { LOGNPM }}{\mathrm{C}}$} & 4.438102 & 0.432686 & 10.25711 & 0.0000 \\
\hline & -1.022166 & 0.101730 & -10.04784 & 0.0000 \\
\hline & \multirow{2}{*}{\multicolumn{2}{|c|}{ Effects Specification }} & & \\
\hline & & & S.D. & Rho \\
\hline \multirow{3}{*}{ Idiosyncratic random } & & & 1.063346 & 0.9348 \\
\hline & & & 0.280737 & 0.0652 \\
\hline & \multicolumn{3}{|c|}{ Weighted Statistics } & \\
\hline R-squared & 0.708861 & \multicolumn{2}{|c|}{ Mean dependent var } & 0.227544 \\
\hline Adjusted R-squared & 0.701199 & \multicolumn{2}{|c|}{ S.D. dependent yar. } & 0.536487 \\
\hline S.E. of regression & 0.293258 & \multirow{2}{*}{\multicolumn{2}{|c|}{$\begin{array}{l}\text { Sum squared resid } \\
\text { Durbin-Watson stat }\end{array}$}} & 3.268017 \\
\hline F-statistic & 92.52168 & & & 1.164935 \\
\hline \multirow[t]{2}{*}{ Prob(F-statistic) } & 0.000000 & & & \\
\hline & \multicolumn{3}{|c|}{ Unweighted Statistics } & \\
\hline R-squared & -0.204743 & \multirow{2}{*}{\multicolumn{2}{|c|}{$\begin{array}{l}\text { Mean dependent var } \\
\text { Durbin-Watson stat }\end{array}$}} & 1.738693 \\
\hline Sum squared resid & 58.37078 & & & 0.065221 \\
\hline
\end{tabular}

3) Pengaruh Debt To Asset Ratio terhadap Price Earning Ratio

\section{Tabel 4.15}

Analisis Regresi Data Panel Secara

Parsial

Pengaruh DAR terhadap PER

\begin{tabular}{|c|c|c|c|c|}
\hline \multicolumn{5}{|c|}{$\begin{array}{l}\text { Dependent Variable: LOGPER } \\
\text { Method: Panel EGLS (Cross-section random effects) } \\
\text { Date: } 09 / 06 / 17 \text { Time: } 06: 39 \\
\text { Sample: } 20132016 \\
\text { Periods included: } 4 \\
\text { Cross-sections included: } 10 \\
\text { Total panel (balanced) observations: } 40 \\
\text { Swamy and Arora estimator of component variances }\end{array}$} \\
\hline Variable & Coefficient & Std. Error & t-Statistic & Prob. \\
\hline $\begin{array}{c}\mathrm{C} \\
\text { LOGDAR }\end{array}$ & $\begin{array}{r}4.972291 \\
-0.884249\end{array}$ & $\begin{array}{l}1.745506 \\
0.470419\end{array}$ & $\begin{array}{r}2.848623 \\
-1.879704\end{array}$ & $\begin{array}{l}0.0071 \\
0.0678\end{array}$ \\
\hline \multicolumn{4}{|c|}{ Effects Specification } & Rho \\
\hline $\begin{array}{l}\text { Cross-section randon } \\
\text { Idiosyncratic random }\end{array}$ & & & $\begin{array}{l}0.886398 \\
0.596502\end{array}$ & $\begin{array}{l}0.6883 \\
0.3117\end{array}$ \\
\hline \multicolumn{5}{|c|}{ Weighted Statistics } \\
\hline $\begin{array}{l}\text { R-squared } \\
\text { Adjusted R-squared } \\
\text { S.E. of regression } \\
\text { F-statistic } \\
\text { Prob(F-statistic) }\end{array}$ & $\begin{array}{l}0.087135 \\
0.063112 \\
0.588731 \\
3.627186 \\
0.064434\end{array}$ & \multicolumn{2}{|c|}{$\begin{array}{l}\text { Mean dependent var } \\
\text { S.D. dependent yar. } \\
\text { Sum squared crsid } \\
\text { Durbin-Watson stat }\end{array}$} & $\begin{array}{l}0.554480 \\
0.608237 \\
13.17094 \\
1.632553\end{array}$ \\
\hline \multicolumn{5}{|c|}{ Unweighted Statistics } \\
\hline $\begin{array}{l}\text { R-squared } \\
\text { Sum squared resid }\end{array}$ & $\begin{array}{l}0.208955 \\
38.32676\end{array}$ & $\begin{array}{l}\text { Mean dependent } y \\
\text { Durbin-Watson sta }\end{array}$ & & $\begin{array}{l}1.738693 \\
0.561024\end{array}$ \\
\hline
\end{tabular}

b. Pengaruh variabel CR, NPM dan DAR terhadap PER Secara Simultan (Uji F).

Tabel 4.16

Analisis Regresi Data Panel Secara

Simultan

Pengaruh CR, NPM dan DAR terhadap PER 
Dependent Variable: LOGPER

-section random effects)

6/17 Time: 06:41

Sample: 20132016

Cross-sections included: 10

Total panel (balanced) observations: 40

Swamo and Arora estimator of component variances

\begin{tabular}{|c|c|c|c|c|}
\hline Variable & Coefficient & Std. Error & t-Statistic & Prob. \\
\hline c & 4.891640 & 1.499958 & 3.261185 & 0.0024 \\
\hline $\mathrm{CR}$ & 0.099813 & 0.046852 & 2.130392 & 0.0400 \\
\hline LOGNPM & -0.994119 & 0.095546 & -10.40458 & 0.0000 \\
\hline LOGDAR & -0.215550 & 0.377820 & -0.570511 & 0.5719 \\
\hline \multicolumn{5}{|c|}{ Effects Specification } \\
\hline & & & & \\
\hline Cross-section random & & & 1.046040 & 0.9416 \\
\hline Idiosyncratic ra & & & 0.260523 & 0.0584 \\
\hline \multicolumn{5}{|c|}{ Weighted Statistics } \\
\hline R-squared & 0.761762 & \multirow{4}{*}{\multicolumn{2}{|c|}{$\begin{array}{l}\text { Mean dependent var } \\
\text { S.D. dependent yar } \\
\text { Sum squared resid } \\
\text { Durbin-Watson stat }\end{array}$}} & 0.214857 \\
\hline Adjusted R-squared & 0.741909 & & & 0.534804 \\
\hline S.E. of regression & 0.271695 & & & 2.657445 \\
\hline F-statistic & 38.36989 & & & 1.166878 \\
\hline Prob(F-statistic) & 0.000000 & & & \\
\hline \multicolumn{5}{|c|}{ Unweighted Statistics } \\
\hline & -0.120573 & \multirow{2}{*}{\multicolumn{2}{|c|}{$\begin{array}{l}\text { Mean dependent var } \\
\text { Durbin-Watson stat }\end{array}$}} & 1.738693 \\
\hline Sum squared resid & 54.29266 & & & 0.057115 \\
\hline
\end{tabular}

c. Pengujian Coefficient of Determination (Adjusted R-Square)

Berdasarkan tabel 4.16 hasilnya adalah Adjusted R-Squre dengan 0,741909. Dengan kata lain, persentase variabel independen terhadap variabel dependen yaitu 74.20\%. kemudian $25.80 \%$ lainnya dikarenakan faktor lain.

\section{d. Persamaan Model Regresi CR, NPM dan DAR terhadap PER}

Dapat terlihat bahwa pada Eviews 9 tabel 4.16 tersebut, diketahui persamaan model regresi antara variabel CR, NPM dan DAR terhadap PER yaitu sebagai berikut:

$$
\begin{aligned}
& \mathrm{Y}=4,891640+0,099813 \mathrm{CR}- \\
& 0,994119 \mathrm{NPM}-0.215550 \mathrm{DAR}
\end{aligned}
$$

Dari nilai persamaan berikut dapat dijabarkan dan dianalisa seperti dibawah ini: a) Dengan nilai konstanta 4,891640 mengartikan bahwa (CR, NPM dan DAR) diakui konstan, dapat dikatakan nilai PER sebesar 4,891640.

b) Nilai dari koefisien regresi yaitu 0,099813 maka setiap penambahan CR 1\% maka akan menambahkan nilai PER sebesar 0,099813.

c) Nilai dari koefisien regresi 0,994119 maka setiap NPM mengalami turun sebesar $1 \%$ maka nilai PER juga akan turun sebesar 0,994119. Nilai dari koefisien regresi -0.215550 maka setiap DAR bertambah sebesar $1 \%$ nilai PER turun sebesar 0.215550 .

\section{Uji Hipotesis Variabel Price Earning}

\section{Ratio terhadap Dividend Payout}

Ratio.

\section{a. Analisa Regresi Sederhana PER terhadap DPR}

\section{Tabel 4.24}

Analisa Regresi Sederhana antara

\begin{tabular}{|c|c|c|c|c|}
\hline \multicolumn{5}{|c|}{$\begin{array}{l}\text { Dependent Variable: DPR } \\
\text { Method: Panel Least Squares } \\
\text { Date: } 09 / 09 / 17 \text { Time: } 12: 28 \\
\text { Sample: } 20132016 \\
\text { Periods included: } 4 \\
\text { Cross-sections included: } 10 \\
\text { Total panel (balanced) observations: } 40\end{array}$} \\
\hline Variable & Coefficient & Std. Error & t-Statistic & Prob. \\
\hline $\begin{array}{c}\mathrm{C} \\
\text { LOGPER }\end{array}$ & $\begin{array}{r}-0.559280 \\
0.763953\end{array}$ & $\begin{array}{l}0.296614 \\
0.163592\end{array}$ & $\begin{array}{r}-1.885547 \\
4.669873\end{array}$ & $\begin{array}{l}0.0694 \\
0.0001\end{array}$ \\
\hline \multicolumn{5}{|c|}{ Effects Specification } \\
\hline \multicolumn{5}{|c|}{ Cross-section fixed (dummy variables) } \\
\hline $\begin{array}{l}\text { R-squared } \\
\text { Adjusted R-squared } \\
\text { S.E. of regression } \\
\text { Sum squared resid } \\
\text { Log likelihood } \\
\text { F-statistic } \\
\text { Prob(F-statistic) }\end{array}$ & $\begin{array}{r}0.687312 \\
0.579489 \\
0.532019 \\
8.208295 \\
-25.08286 \\
6.374424 \\
0.000041\end{array}$ & $\begin{array}{l}\text { Mean depende } \\
\text { S.D. depender } \\
\text { Akaike info crit } \\
\text { Schwarz criter } \\
\text { Hannan-Quinn } \\
\text { Durbin-Watsor }\end{array}$ & $\begin{array}{l}\text { tyar } \\
\text { var } \\
\text { rion } \\
\text { in } \\
\text { criter. } \\
\text { stat }\end{array}$ & $\begin{array}{l}0.769000 \\
0.820425 \\
1.804143 \\
2.268585 \\
1.972070 \\
1.183245\end{array}$ \\
\hline
\end{tabular}
variabel PER terhadap DPR 


\section{b. Pengujian Koefisien Determinasi}

Untuk mengetahui seberapa besar pengaruh variabel bebas terhadap variabel terikat dapat dilakukan dengan koefisien determinasi $\left(\mathrm{R}^{2}\right)$.

Dapat dilihat bahwa tabel 4.24 angka Adjusted R-Squre yaitu 0,579489. Dapat dikatakan persentase variabel bebas terhadap variabel terikat yaitu $57.95 \%$. kemudian $42.05 \%$ lainnya karena faktor lain.

\section{c. Persamaan Model Regresi PER terhadap DPR}

Penelitian dengan regresi data panel digunakan untuk melihat pengaruh antara variabel independen terhadap variabel dependen. Hubungan fluktuasi variabel dependen dan faktor-faktor fundamental yang mempengaruhinya dapat diformulasikan. Berdasarkan Eviews 9 tabel 4.24 diatas, maka diperoleh persamaan model regresi antara variabel PER terhadap DPR yaitu sebagai berikut:

$$
\mathrm{Y}=-0.559280+0.763953 \text { PER }
$$

Dari hasil persamaan regresi linier berganda di atas dapat di analisis sebagai berikut:"

a) Konstanta sebesar -0.5592890 menyatakan bahwa jika variabel bebas (PER) dianggap konstan, maka nilai PER sebesar 0.5592890 .

b) Koefisien regresi sebesar 0.763953 menyatakan bahwa setiap penambahan PER sebesar 1\% maka akan meningkatkan nilai DPR sebesar 0,763953 .

\section{V.PENUTUP}

A. Kesimpulan

1. Likuiditas memiliki pengaruh terhadap Nilai Perusahaan. Dimana secara parsial, uji hipotesis Current Ratio terhadap Price Earning Ratio yang dijadikan sebagai alat ukur memiliki pengaruh positif dan signifikan dengan (2.200547> 2,02809) dan CR lebih rendah dari konstanta $(0,0339<0,05)$.

2. Profitabilitas memiliki pengaruh terhadap Nilai Perusahaan. Dikarenakan keuntungan atau laba yang didapatkan perusahaan akan meningkatkan modal dan saham perusahaan. Dimana secara parsial, uji hipotesis Net Profit Margin terhadap Price Earning Ratio yang dijadikan alat ukur memiliki pengaruh negative namun tidak signifikan dengan t-hitung lebih kecil dari t-tabel $(-10.04784$ < 2,02809) dan nilai probabilitas Net 
Profit Margin lebih besar dari konstanta $(0,0640>0.05)$.

3. Leverage tidak memiliki pengaruh terhadap Nilai Perusahaan. Dimana secara parsial, uji hipotesis Debt To Asset Ratio terhadap Price Earning Ratio yang dijadikan sebagai alat ukur tidak memiliki pengaruh dan tidak signifikan dengan t-hitung lebih kecil dari t-tabel (-1.879704 < 2,02809) dan nilai probabilitas DAR lebih besar dari konstanta $(0.0678<0.05)$.

4. Likuiditas, Profitabilitas dan Leverage memiliki pengaruh terhadap Nilai perusahaan. Dimana secara simultan, uji hipotesis Current Ratio, Net Profit Margin dan Debt To Asset Ratio terhadap Price Earning Ratio yang dijadikan sebagai alat ukur memiliki pengaruh dan signifikan dengan $\mathrm{F}$ hitung $>\mathrm{F}$ tabel (38.36989 > 2,87) dan hasil (prob) 0,000000 lebih rendah dari 0,05 , dengan persentase keterkaitan antara variable dependen terhadap variabel dependen sebesar $74.20 \%$, sedangkan sisanya $25.80 \%$ dipengaruhi faktor lain.

5. Nilai Perusahaan memiliki pengaruh terhadap Kebijakan
Deviden. Dimana secara parsial, uji hipotesis Price Earning Ratio terhadap Dividend Payout Ratio yang dijadikan sebagai alat ukur memiliki pengaruh dan signifikan dengan Ftabel $<\mathrm{F}$ hitung $(4,10<$ 6.374424) dan aangka (prob) Senilai 0,0001 yang lebih rendah dari 0,05 .

\section{B. Saran}

1. Ada baiknya jika dalam penelitian selanjutnya untuk menambah jumlah variabel agar hasil dari penelitian lebih akurat. Selanjutnya untuk menilai bahwa perusahaan tersebut baik atau tidak dapat pula digunakan alat ukut Tobins Q sebagai alternative dari Price Earning Ratio (PER). Dan untuk lebih menambah wawasan terhadap perkembangan penyusunan tesis, ada baiknya objek yang digunakan tidak selalu berasal dari Indonesia, namun dari negara-negara lain.

2. Perusahaan perlu memperhatikan dan mempertimbangkan hutang yang dibiayai oleh asset, dikarenakan jika hutang perusahaan tinggi dan tidak berbanding lurus dengan asset yang dipunyai maka akan 
menurunkan nilai suatu perusahaan

3. Aktiva lancar yang sehat atau baik sangat berpengaruh terhadap nilai perusahaan dalam arti harga saham dan laba perusahaan, ada baiknya variabel tersebut dioptimalkan dengan efektif dan efisien.

\section{DAFTAR PUSTAKA}

Sartono, Agus. 2001. Manajemen Keuangan Teori dan Aplikasi , Edisi IV.Yogyakarta: BPFE.

Alexandri, Mohammad Benny. 2008. Manajemen Keuangan Bisnis . Cetakan Kesatu. Bandung: Alfabeta.

Brigham dan Houston. 2010. Dasar-dasar Manajemen Keuangan Buku 1 (Edisi II). Jakarta: Salemba Empat

Fahmi, Irham. 2013. Analisis Laporan Keuangan. Bandung: Alfabeta.

Harahap, Sofyan Syafri. 2015. Analisi Kritis atas Laporan Keuangan. Edisi 1-10. Jakarta: Rajawali Pers.

Kasmir, "Pengantar Manajemen Keuangan”, Edisi Pertama, Kencana, Jakarta. 2010.

Kasmir. 2015. Analisis Laporan Keuangan. Edisi 1-8. Jakarta: Rajawali Pers.

Keown, Arthur J., David F. Scott, Jr., John D.. Martin, J. William Petty. 2010. Manajemen Keuangan "prinsip dan penerapan jilid 2. Edisi 10. Jakarta: PT. Indeks.

Oktrima, B., \& Riani, N. (2019). PENGARUH PERPUTARAN KAS DAN PERPUTARAN PIUTANG TERHADAP RETURN ON
INVESTMENT (ROI) PADA PT. SEMEN INDONESIA (PERSERO) TBK PERIODE TAHUN 2008-2017. Jurnal Ekonomi Efektif, 2(1

Purnomo, S., \& Pasaribu, V. L. D. (2019). Pergerakan Harga Saham Pt Adaro Energy Tbk (Adro) Pada Pengumuman Dividen Interim Tahun Buku 2018. Jurnal Ekonomi Efektif, 2(1).

Riyanto, Bambang. 2011. Dasar-Dasar Pembelanjaan Perusahaan (Edisi 4). Yogyakarta : BPFE.

Simamora, Henry. 2000. Basis Pengambilan Keputusan Bisnis. Jakarta: Salemba Empat.

Sugiyono. (2007). Metode Penelitian pedidikan pendekatan kuantitatif,kualitatif, dan R\&D.Bandung: ALFABETA

Sriayana, J. 2014, Metodologi Regresi Data Panel, Yogyakarta, Ekonisia.

Sugiyono, "Statistika Untuk Penelitian", Alfabeta, Bandung. 2011.

Sugiyono, 2017, Metode Penelitian kuantitatif, Kualitatif, R\&D. Bandung: Penerbit Alfabet.

Sunariyah. 2004. Pengantar Pengetahuan Pasar ModalEdisi Keempat. Yogyakarta : UPP AMP YKPN.

Untung, dan Hartini. (2006). Implikasi Struktur Kepemilikan Terhadap Nilai Perusahaan: Dengan Keputusan Keuangan Sebagai Variabel Intervening. Simposium Nasional Akuntansi 9

Virby, S. (2017). Pengaruh Indeks Dow Jones Industrial Average, Nikkei 225, Hangseng Index, dan Shanghai Stock Exchange terhadap Indeks Harga Saham Gabungan Bursa Efek Indonesia Periode Tahun 20082013. INOVASI, 4(2). 
Page | 81 